\title{
Choosing to Work? Mothers Return-to-Work Decisions, Social Class, and the Local Labor Market
}

1 Tiina Sihto'

Doctoral student, Department of Social Sciences and Philosophy, University of Jyväskylä, Finland

\begin{abstract}
The aim of this study is to examine the ways in which social class shapes the return-to-work decisions of Finnish working-class and middle-class mothers, and how these decisions are structured by the constraints and opportunities mothers face in the local labor market. The focus of the study is in the local labor market of the city of Jyväskylä. The data consist of two semi-structured focus group interviews of 14 employed mothers of below school-age children. Using the framework of "gendered moral rationalities," the study shows that there are similarities in mothers' experiences, while the structural constraints mothers faced when deciding about the timing of returning back to work differ. The analysis highlights that the differences were not only dependent on social class but also on the situation in the local labor market. For working-class mothers, the most crucial issue was the financial strain that their staying at home caused to their families. For middle-class mothers, finding employment opportunities that would match their educational qualifications in the local labor market had been challenging, which affected their timing of returning back to work. The paper concludes that local labor market plays an important role in mother's return-to-work decisions and should be explored further in differing geographical contexts.
\end{abstract}

\section{KEY WORDS}

Childcare / female employment / local labor market / social class

\section{Introduction}

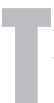

he aim of this study is to examine the ways in which social class shapes the returnto-work decisions of Finnish working-class and middle-class mothers, and how these decisions are structured by the constraints and opportunities mothers face in the local labor market. Motherhood is usually seen as a classless activity, even though it has been found in previous research that there are class-based differences, for example, in mother's childrearing practices (Walkerdine \& Lucey, 1989) and in how mothers reconcile employment and childcare (Duncan, 2005). Previous studies have also explored the connection between social class and parenting in the "egalitarian" Nordic countries (e.g., Forsberg, 2009; Stefansen \& Farstad, 2010). Even though the social democratic welfare states have aimed to equalizing the opportunity structure for their citizens (Esping-Andersen, 2014), a class ingredient can also be found in the context of Nordic family policies; universalist family policies that aim for class and gender equality can also become "building blocks in classed care strategies" (Stefansen \& Farstad, 2010). However, there are less studies on class-based differences on mothering in Finland (however, see Kelhä, 2008), and particularly on the effect of social class in maternal employment

\footnotetext{
${ }^{1}$ E-mail: tiina.sihto@jyu.fi
} 
and the reconciliation of work and childcare. In this article, the interest is in exploring how social class is reflected in the ways Finnish mothers describe their employment decisions and returning back to employment.

The studies regarding maternal employment have mainly focused on national comparisons, while local labor markets have not received much attention. However, previous studies have shown how the employment opportunities provided by the local labor market are crucial particularly to women with dependent children (e.g., Wheatley, 2013; Yeandle et al., 2009). This article sets out to examine how class and spatiality, together and separately, structure different kind of possibilities for mothers regarding returning back to work in the local labor market of Jyväskylä, a city located in Central Finland. In this article, the interest is particularly on exploring mothers' reasons for returning back to employment, the timing of returning back to work, and the role of the local labor market in mothers' return-to-work decisions.

\section{Mothering, class, and gendered moral rationalities}

Since the 1980s until recent years, social class has been a rather neglected concept both in sociological research and public discussion in Finland. After the strong politicization of the concept of class in the 1970s, the term almost disappeared from the social research agenda for over two decades (Erola, 2010: p. 8; Tolonen, 2008: p. 9). Blurring of traditional social classes due to changes in working life, consumption, and lifestyle also made class increasingly problematic to define. Especially during the time of rapid expansion of the welfare state in the 1980s, it was widely believed that all Finns were becoming "one big middle class" and that eventually, class-based differences would cease to exist (Tolonen, 2008: pp. 8-9). However, during recent years, the discussion about class differences has livened up. Both Erola (2010: p. 7) and Tolonen (2008: p. 10) suggest that this is due to the widening income differences and polarization of the Finnish society; "one big middle class" does not seem to be the reality anymore, if it ever was.

Social class is much-debated concept with several different definitions. Following Beverley Skeggs (1997, p. 5), social class is here defined as a discursive, historically specific construction that is central in influencing access to economic and cultural resources. For working-class women who have limited access to these resources, caring constitutes a specific form of feminine cultural capital that offers a possibility to become "respectable" (Skeggs, 1997: p. 10). Thus, for working-class women with insecure position in the labor market, "investing" in care and motherhood is accepted, even expected (Käyhkö, 2006).

The timing of motherhood and employment (Walkerdine et al., 2001) and work orientations differ between working-class and middle-class mothers (e.g., James, 2008; Hebson, 2009). James (2008) argues that due to the greater economic and educational capital, middle-class women have a freer choice between work and home-making than working-class women. Thus, for working-class women, employment is a financial necessity, whereas for middle-class women, work is important itself, as central to their sense of self. The dichotomy of middle-class choice and working-class (financial) need suggests that middle-class work is voluntary and working-class work is involuntary, implying that middle-class work is more rewarding, more desirable, and more sought after (Damaske, 2011: p. 67).

Duncan (2005) uses the concept of "gendered moral rationalities" to examine working-class and middle-class mothers' decision-making regarding employment. Gendered 
moral rationalities refer to the socially negotiated ideas, which are considered as the "proper thing" for mothers to do in relation to employment. Mothers' gendered rationalities vary between three "ideal types": 1) "primarily mothers," who give primacy to physically caring for their children; 2) "primarily workers," who view paid work as separate for themselves, as separate to their identity as mothers; and 3) "mother/worker integrals," who see full-time employment and financial provision through employment is part of "good mothering" (Duncan \& Edwards, 1999: p. 120). Using the gendered moral rationalities approach, Duncan (ibid.) shows how mothers' decisions are shaped by class, although not determined by it, and how women with the same class position can have differing orientations toward mothering and employment. According to Duncan (ibid., 73), gendered moral rationalities are also shaped by the geographic context, as "regionally specific gender cultures" are bound up with the class divisions in mothering.

\section{Maternal employment and mothers' return-to-work decisions}

In Finland, the majority of women are in employment, including mothers of young children. In 2014, the employment rate of women aged 15-64 years was $67.9 \%$. The employment rate of men was somewhat higher, being 68.7\%. (Statistics Finland, 2015.) Despite the high level of participation in employment, women still have a more vulnerable position in the labor market. The labor market is strongly segregated (Mikkelä, 2013) and the gender wage gap remains relatively high (Statistics Finland, 2014). Both (involuntary) temporary and (involuntary) part-time employment are more common among women than men (Kauhanen, 2013: pp. 52-53). Temporary work contracts are particularly common among women of childbearing age (aged 25-34 years) (Sutela, 2013). The employment situation of mothers of young children is especially vulnerable: in 2013, one-third of mothers with children below the age of 3 did not have an existing employment contract (Statistics Finland, 2013).

In a study by Kaisa Kauppinen and Jani Raitanen (2011) on the issues that influence mothers' return to work after childcare leave, the most central factor in returning to work was the need to secure the income of the family. Other factors that contributed to mothers' return to work were the interest felt toward one's work, social relations at the workplace, possibility for flexible work arrangements, and a spouse who was able to stay at home with the child(ren). However, one-fifth of the respondents expressed the importance of taking care of their children at home and stated that returning to work was not a topical issue at the moment.

The reasons for returning to work differ, as do as the strategies mothers adapt to once they have made the decision to return to work. However, mothers do these decisions from the point of view of what is considered as best for the children and family (Damaske, 2011; Luotonen, 2012, 2013) and with a strong emphasis on "good mothering” (Duncan, 2005). Aino Luotonen (2012, 2013) has divided mothers' return-to-work strategies into three, partly intertwining categories: "soft landing" aims at gradual return from care leave back to employment, for example, by doing occasional shifts at work during care leave. The second strategy, "change of attitude" aims to change one's relationship with work, giving it less emphasis than before having children. "Returning on child's terms" means a radical change in job or career plans, for example, by changing one's field of work or reducing work from full-time to part-time to be able to care for 
the child at home. According to Luotonen (2013: p. 49), those who choose the strategy of returning on child's terms do not experience strong work engagement, and the return is mostly motivated by financial reasons.

\section{Childcare supporting maternal employment}

Childcare is a key issue in maternal employment. By international comparison, the parenthood policies in Finland are well-developed and the support to parents who combine employment and family is rather generous (Salmi, 2006). All children under schoolage have a social right to municipal day care. Maternity allowance is paid until the child is about 3 months old, followed by parental allowance for mother or father until the child is 9 months old. Both maternity and parental leave periods are compensated according to previously taxed earnings. After parental leave, child home care allowance can be claimed by families with a child under the age of 3 who is not in municipal day care and who is looked after by one of the parents or another person (e.g., a relative) or a private day care provider. The child home care allowance is paid at a low flat rate (Kela, 2014.) Currently, approximately $99 \%$ of children under the age of 1 year and $41 \%$ of the children aged $1-2$ years are taken care of at home (National Institute of Health and Welfare, 2014), mostly by mothers. In public discussion, women's long childcare leaves are often seen as problematic for both the national economy and for women's working careers. In 2013, around one-third of mothers of children under 3 years of age were in employment (Statistics Finland, 2013). The strong preference for home care of children under 3 years of age has even led some researchers to argue that Finland has been transformed into a homemaker society (e.g., Anttonen, 2003).

Finland is usually classified as belonging to the Nordic welfare model and being a women-friendly welfare state (see Hernes, 1987). However, there are some country-specific factors that set Finnish family policy apart from other Nordic countries. Grodem (2015) has referred to Finland as the "somewhat muted version" of the Nordic welfare model, and less committed to supporting working mothers and caring fathers than the other Nordic countries. What is particular to Finland is also the strong emphasis on the discourse of families' possibility of choice (Varjonen, 2011: p. 102). This discourse suggests that individual families should have as much freedom as possible in choosing the preferred form of childcare. The discourse of possibility of choice puts emphasis on individuals' (and individual families') decisions and not much attention is given to how these choices in reconciling work and childcare are constructed. "Choice" can be seen as a somewhat controversial concept when used in the context of reconciling work and childcare, since in many ways, these choices seem to be almost predetermined by one's gender (see Kela, 2010), educational level, and labor market position.

For Finnish mothers with high education and good employment opportunities in the labor market, parental leave schemes offer latitude; these mothers can exercise their possibility of choice by choosing to stay on parental leave and/or work part-time and return to work full-time after that. Mothers with lower education and insecure labor market position have fewer alternatives. For this group of women, child home care allowance can also be an alternative to being unemployed. They also use home care allowance more than mothers with high education (Lammi-Taskula, 2004: p. 205). In the end, Finnish family policy offers little security to mothers who do not have a secure place in the labor market (Jokinen, 2005: p. 105). 


\section{The role of local labor market in maternal employment}

There is no uniform definition for the term "local labor market" (e.g., Tervo \& Korhonen, 1994: p. 11; Yeandle et al., 2009: p. 5). From the point of view of the labor force, the local labor market can be defined as the employment opportunities that are within the reach of the labor force without changing the place of residence (Tervo \& Korhonen, 1994: p. 11). However, the geographical range inside of which people are able to seek for employment varies considerably between individuals, and this range is often more narrow to those with caring responsibilities (Yeandle et al., 2009: p. 5). Since this study focuses on employed mothers of young children, following Yeandle et al. (ibid.), the local labor market is here defined as the range of jobs available within easy daily traveling distance from the women's' homes. In practice, for the women interviewed in this study, this meant the city of Jyväskylä and its surrounding municipalities.

The focus of the study is in the local labor market of the city of Jyväskylä, a city of approximately 130,000 inhabitants located in Central Finland. The local labor market of the city has some specific features that separate it from other cities of the same size in Finland. The population in Jyväskylä is relatively young, and the number of young adults is especially high. The educational level of inhabitants is high, especially in younger age cohorts. Around $51.5 \%$ of inhabitants aged $30-39$ years have tertiary education. (City of Jyväskylä, 2011.) The overall unemployment rate in Jyväskylä has been higher than the country average since the 1990s (SOTKANet, 2015a). The rate of unemployment and the relative rate of unemployment for high-educated have risen in the whole Central Finland region since the start of economic recession in 2008 (Ministry of Employment and the Economy, 2015).

Data on local labor markets are extremely difficult to obtain. The most recent data from 2009 show that national employment rates for mothers were much higher than the employment rate of mothers in Jyväskylä. The widest gap in employment rate was among women with children between 1 and 2 years of age; in Jyväskylä, the employment rate was $50.7 \%$, whereas nationally, the employment rate was $58.7 \%$ (Kuronen $\&$ Kröger, 2011). The percentage of children between the ages of 1 and 6 in municipally financed day care was $48 \%$ in 2014 , well below the country average of $57.8 \%$ (SOTKANet, 2015b). These figures suggest that for mothers, staying at home with young children is more common in Jyväskylä than in the rest of Finland on average. Low employment rate of mothers of young children and low percentage of children in municipally financed day care might both also reflect the difficult labor market situation in Jyväskylä, and especially the challenges young, recently graduated women face in establishing their position at the local labor market (see Kuronen \& Kröger, 2011).

\section{Data}

This article is based on two semi-structured focus group interviews of working mothers of children under school age. There were a total of 14 interviewees: 8 in the workingclass mothers group and 6 in the middle-class mothers group. All of the interviewees were living in Jyväskylä and working either in Jyväskylä or in the surrounding municipalities. The interviews were carried out as part of the FLOWS research project (FLOWS: Impact of Local Welfare Systems on Female Labour Force Participation and 
Social Cohesion 2011-2014, European Commission FP7) in 2013. The themes of the interview focused on working life, preferences regarding the form of childcare, and their views on reconciling work and childcare. Both interviews lasted around 3 hours and were conducted in Finnish. For this article, selected excerpts were translated into English.

The focus groups were divided according to interviewees' educational level. In the working-class mothers' group, the interviewees were women with an educational level of ISCED 1-3, having either lower or upper secondary education. In the middle-class mothers' group, the interviewees had the educational level of ISCED 4 or higher. Using the Goldthorpe classification scheme (Goldthorpe, 1980), most of the interviewees in the working-class mothers' group belonged to class category III (routine nonmanual employees), and in the middle-class mothers' group, the interviewees belonged to class category II (lower-grade professionals). There were two self-employed interviewees, one in each group.

The interviewees were recruited through several different routes: in the middleclass mothers' group, the majority were selected from telephonic survey respondents to the FLOWS project, based on their preliminary agreement to participate in a focus group. Researchers of the FLOWS project also used their own personal networks and social media to recruit interviewees. The group of employed working-class mothers was difficult to reach in the city of Jyväskylä via more formal routes, such as the survey respondents' list and advertisements in the local newspaper. However, by using social media, the research team managed to reach the interviewees with little effort.

Table 1 summarizes the key characteristics of the interviewees. The table indicates participants' name (changed to a pseudonym), age, her children's ages, social class, and whether the interviewees worked full-time, part-time, or had non-standard work as a temporary agency worker (Janina) or doing short-term work as a substitute (Raza). The interviewees themselves had to categorize their work either as full-time or part-time. Only the interviewees working 37.5 hours per week or more defined their work as "fulltime" and the ones working 30 hours (or less) categorized their work as "part-time." All interviewees, with one exception, were either married or co-habiting.

In focus group interviews, the participants produce collectively shared understanding of their individual experiences, ideas, and beliefs (Pietilä, 2010: pp. 210-215): the interviewee is not directing what (s)he says just to the interviewer but also to other interviewees. In focus groups, the participants can consider "the ways that they are both similar and different from each other" (Morgan, 1997: p. 12). At best, the participants in focus groups can support and encourage each other, which can lead the interviewees to open up and share insights that would not be available from individual interviews or other data sources (Krueger, 1988: p. 42). Using focus group interviews to study working-class and middle-class mothers' return-to-work decisions offers a way to explore the differences and similarities both between and within the groups regarding the experiences of returning back to employment. However, there are also challenges in conducting and analyzing focus group interviews: when the group reaches a strong consensus on some issue, it might be difficult for the interviewee to express differing opinions. When analyzing focus group data, the particular social context of the interview situation should be taken into consideration. Besides which topics are brought up, it is also essential to note which topics remain hidden (Heikkilä, 2008: p. 294). 
Table I Interviewees

\begin{tabular}{lccll}
\hline Name & Age & Children's ages & Social class & Working hours \\
\hline Satu & $40-49$ & $3,12,17$ & Working-class & Full-time \\
\hline Saana & $30-39$ & 1,6 & Working-class & Part-time \\
\hline Anniina & $20-29$ & 2 & Working-class & Full-time \\
\hline Sointu & $30-39$ & 4 & Working-class & Full-time \\
\hline Raza & $20-29$ & 1,2 & Working-class & Non-standard \\
\hline liris & $20-29$ & 1,3 & Working-class & Part-time \\
\hline Janina & $20-29$ & 4,6 & Working-class & Non-standard \\
\hline Liisa & $20-29$ & 2 & Working-class & Part-time \\
\hline Maria & $30-39$ & 4 & Middle-class & Full-time \\
\hline Noora & $30-39$ & 2,3 & Middle-class & Full-time \\
\hline Riikka & $30-39$ & 5 & Middle-class & Full-time \\
\hline Sari & $30-39$ & 2 & Middle-class & Part-time \\
\hline Johanna & $30-39$ & $3,7,10,14$ & Middle-class & Full-time \\
\hline Ulla & $40-49$ & &
\end{tabular}

\section{Thematic analysis}

The data in this article were analyzed using thematic analysis. Thematic analysis is a method for identifying, analyzing, and reporting patterns within the data, and theorizing the significance of these patterns and their broader meanings and implications. The analysis was carried out using the guidelines of Braun and Clarke (2006), who divide thematic analysis into six phases. The first phase was familiarizing with the data. Before I started reading the transcripts, I was somewhat familiar with the data. I had been present in the interview situations as an assistant/organizer and involved with the transcribing of the interviews. After reading and re-reading the data, I started generating initial codes from the data. At this stage, I was broadly looking at the way interviewees talk about the preferences, choices, possibilities, and obstacles they had faced in reconciling work and childcare, without any particular thematic focus. The coding was done by using qualitative data analysis software ATLAS.ti.

The third step of analysis was searching for themes, followed by reviewing the themes. The interviews were in themselves thematic: the interviews divided roughly into four parts, with different focuses. The themes of the interviews were 1) women's work; 2) childcare arrangements; 3) facilitators of, and barriers to, mother's working lives; and 4) facilitating women's working lives and policy change. However, as Braun and Clarke (2006: p. 15) point out, dividing themes in the analysis according to questions put to participants is not analysis. The themes should be searched across the data set to find repeated patterns of meaning. Often the themes structured by the questions were overlapping (e.g., when talking about childcare, the interviewees also spoke about their employment situation, or vice versa), which made constructing new themes on the basis 
of the data crucial to the analysis. After searching and reviewing the themes, the fifth step of the analysis was defining and naming the themes. At this stage, the following five themes were analyzed: 1) employment decisions; 2) the effect of childcare for mother's employment; 3 ) role of spouse and other family members; 4) policy recommendations for work-family reconciliation; and 5) ideal work-life balance.

After searching, reviewing, defining, and naming of the themes, it became apparent that a more specific focus would be needed for this study. This led me to focus more specifically on the first theme, employment decisions, discussed in this article. The codes that were used in identifying the theme employment decisions were words and phrases that the interviewees used to describe the various factors that affected their current employment participation. The sixth step, final analysis, presented in the next chapter, is based on the analysis of this theme. The analysis was done in relation to the research questions, focusing on 1) the reasons for mothers to return to work after childcare leave, 2) the timing of returning to work, and 3) mothers' views on their position in the local labor market as working mothers.

\section{Findings}

\section{Mothers and workers-The importance of two roles}

All of the interviewees were living their "peak years," balancing between the demands of work and family. Due to the recruiting criteria for the interviewees, they were all employed mothers of children below the school age. This led to the fact that they had all made significant decisions regarding care of their child(ren) and employment during past years. They had all been faced with questions such as what form of childcare was best for their child(ren), how long should they stay at home with their child(ren), and if and when should they return to work.

In their orientation toward work, the interviewees in both groups held similar kind of "gendered moral rationalities" (Duncan, 2005). The interviewees had strong "primarily worker" understandings of the role of employment in their lives and expressed the importance of having "two roles," as both mothers and workers. Working-class Iiris described how after returning to work, she had "found myself again, as a worker and as a woman. Sometimes it is relieving to be something else than just a mother." The interviewees in both groups stressed the importance of the separateness of these two roles. In the same time, the interviewees emphasized how being a mother had made them better workers. Middle-class Noora pointed out the positive impact of motherhood on her work explaining how "I feel that I have become a better worker, I know now better how to react to the teenagers' turmoil at work when I look at my own three-year-old childs' turmoil at home." Middle-class Sari emphasized how having a child helps her to detach from her knowledge-intensive work during her free time, and due to this detachment, the hours she spends at work, she spends "super efficiently." Interestingly, the interviewees in both groups emphasized how being a mother had a positive impact on their input as workers, but spoke relatively little about working as part of good mothering. Only working-class Sointu strongly expressed the "mother/worker integral" understanding of being a working mother, seeing employment as part of being a good mother and important in setting an example for her child: 
"It's nice to start the cold car and scrape the car windows and leave for work feeling proud and give this kind of an example for the child that this will be ahead for you too. That there are other ways of living, but that everyone does some sort of work at some point in their lives."

The interviewees' strong identities as workers were also reflected in the fact that returning to work after childcare leave had been self-evident to all of the interviewees; in the course of the interviews, none of the interviewees expressed that they would want to quit working altogether, even if given the completely (financially) free choice. As noted in the previous research (e.g., Julkunen, 2010), the cultural norm of the dual-worker/ dual-carer model in families is strong in Nordic countries, meaning that parents of both genders are expected to participate in paid employment and in childcare. However, the gendered nature of reconciling work and childcare was apparent in both focus groups; in most cases, the interviewees were the ones carrying the main responsibility for the "second shift" (Hochschild, 1989) of housework and childcare, and the interviewees were also the ones who made the choices related to childcare in their families.

When they were asked about the positive aspects of work, the responses were similar between the groups and similar to responses in the study by Kauppinen and Raitanen (2011): work offers steady income, social contacts, and "a sense of purpose." The interviewees in both groups also pointed out the concreteness of the work as a positive aspect, and how at work, "you feel like you have done something real," as emphasized by working-class Janina. This concreteness was contrasted with the repetitiveness of housework. Middle-class Riikka explained how "if you get something done [at work], it's more than a table you wipe with a cloth that looks exactly the same after five minutes. The concreteness is rewarding, that when you get some fancy report done (laughs) then it's like a mark in the world."

Contrary to the idea that working-class women need to work for financial reasons while middle-class women choose to work, it became apparent in our focus groups that working-class women did not base their return-to-work decisions solely on financial needs and middle-class women did not feel awash with countless possibilities. In our interviews, the orientation toward work was indeed more practical in the working-class mothers' group, although identification with work was not solely a middleclass characteristic (Damaske, 2011: p. 137). In the course of the interview, it became apparent that work was not only a source of income or "choice" made involuntarily. All of the interviewees in the working-class mothers' group did human service work and emphasized the importance of adult social contact and positive feedback from clients or customers in the workplace among the major positive aspects of work. None of the working-class interviewees talked about career-advancement or importance of the content of work, but they expressed a strong pride in being working mothers. The pride felt in working was also one of the factors that motivated them to return to work.

When compared with working-class mothers, in the middle-class mothers' group, there was less talk about pride felt in working itself, and more emphasis put on the importance of the content of work. Work was described as "a constant source of inspiration" (Sari), and the enthusiasm felt toward work was one of the factors that motivated the interviewees to return to work. For some middle-class interviewees, the autonomy of work, and flexibility of working times, facilitated returning to work sooner. Sari stated 
that if she did not have flexible working times, she "wouldn't have returned to work straight from maternity leave."

The interviewees in both working-class and middle-class groups expressed the view that the choices related to work and the timing of returning to work were made on their children's terms. "Returning on child's terms" was one of the three return-to-work strategies distinguished by Luotonen $(2012,2013)$. This strategy appears as a radical change in one's job or career plans. However, out of the interviewees, only middle-class Johanna had adapted to this strategy. Out of the interviewees in both groups, Johanna emphasized most strongly the "primarily mother" views on combining work and childcare. For her, returning to work had meant changing her field of work and reducing working hours:

"For me, the child is the dominant factor. Because of the child I live in Jyväskylä and I work where I work and I work the hours I work, six and half hours per day, so that we don't have to rush in the mornings and I get to leave home a bit earlier. Having a child, basically, dictates $95 \%$ of my choices."

Following Johanna, the other interviewees in the middle-class mothers' group also emphasized returning on child's terms and there was a strong group consensus on this issue. Also in Duncan's (2005: p. 65) study, most mothers expressed similar feelings and as Duncan states, to do otherwise would be considered "bad mothering." Putting the children first and being a good mother is a strong cultural norm. This norm of being a good mother can contradict the norm of being an ideal worker, who proves her commitment to work by being available for work at all times (see Lewis, 1991). The pressures of being both a good mother and an ideal worker were felt in both groups. The middleclass mothers especially felt that in order to get a job, one has to "be flexible and willing to work overtime" (Sari) and be willing to devote one's free time to advancing in one's career, otherwise "you are left behind when compared to others" (Maria).

In the working-class mothers group, the norm of being an ideal worker, who is available for work at all times, was felt especially by Raza and Janina, who were both doing non-standard work, Raza as a substitute in nursing homes and Janina as a cashier through a labor hire company. The work through labor hire companies was seen as a form of work that does not benefit mothers of small children, since the job offers come up suddenly, and to get the shift, one has to be able to react fast to the work that has been offered. To be able to work in the shifts offered by labor hire companies, the interviewees felt that one should have a strong and flexible support network, enabling them to react to job opportunities quickly before the offered shift went to somebody else. For the interviewees who were doing non-standard work, social capital in the form of social networks consisting of grandparents and other close relatives were essential. These informal care resources function as "informal care capital," a form of social capital that functions as a resource in reconciling work and (child)care (Chou \& Kröger, 2014).

\section{Choosing employment? The timing of returning to work}

When choosing the timing of employment, the interviewees in both groups emphasized that the main priority was finding suitable care arrangements for the child before the 
mothers would start in employment. The cultural ideals of childcare were similar for both working-class and middle-class mothers. In both groups, the "sheltered space" for care (Stefansen \& Farstad, 2010), which emphasizes the child's need to be at home in a safe environment, was considered as ideal. The interviewees in both groups preferred to have the parent (usually mother) staying with the child at home at least until the child was 1 year old, and after that either to use "home-like" care provided by a private childminder or to have mother continue stay at home with the child. In a study on Norwegian parents by Stefansen \& Farstad (2010), the "sheltered space" for care was considered as an ideal model of care by mostly working-class parents. The interviewees of our study, however, regardless of class, emphasized the importance of home care or "home-like" care, especially for children below the age of 3 .

Previous research has shown that the preference for home care of children below the age of 3 is stronger in Finland than in other Nordic countries (e.g., Hiilamo \& Kangas, 2006), which can also be reflected from the strong shared ideal of "sheltered space" for care expressed by the interviewees regardless of social class. The majority of interviewees in both groups had adopted the "primarily mother" understandings in relation to work and childcare when the child was below the age of 1 . The "primarily mother" understandings shifted toward the "primarily worker" views once the child was seen as old enough to enroll in day care.

In general, working-class mothers returned to work somewhat sooner than middle-class mothers, although the overall differences between the groups remained low. When choosing the timing of returning to work, the majority of the interviewees in both groups had returned to work around the time when their (youngest) child was 1 year old and all interviewees had returned to work by the time the (youngest) child was 3 years old. Even though the interviewees in both groups had similar childcare preferences and their timing in returning back to work did not differ significantly, there were differences between the groups regarding how they chose the timing of returning back to work. For working-class mothers, the financial situation of the family was essential when making the decision of returning back to employment. For middle-class mothers, the most crucial issue was finding a job suitable to their skills in the local labor market.

Six of the eight interviewees in the working-class mothers' group had returned to work when their (youngest) child was 1 year old or younger. Four of these interviewees expressed that they had to return to work sooner than they expected due to the financial strain that their staying at home caused to their family. For these women, lack of economic resources was the main factor in deciding the timing of their return to work and they wished they could have stayed at home with their child(ren) for longer, which caused ambivalent feelings regarding returning back to work. As noted earlier in the analysis, working-class women described work as important for themselves, as a separate role from being a mother, and held strong "primarily worker" understandings once they had returned back to work. However, returning back to work sooner than they had hoped for and what they saw as suitable age for daycare enrollment for their child was contradictory to their "primarily mother" views on what they considered as the "proper" thing for a mother to do in relation to employment. As Iiris described:

"I have made the kind of decisions that I grieved a lot in advance, for example when I had to put my children to daycare at this age ... But I don't feel sorry at all anymore. Of course 
I get a bit teary-eyed during the work day when I remember what the toddler said and did and so on, and I miss them.”

In the middle-class mothers' group, the interviewees had returned to work when the children were somewhat older than the working-class mothers' group. Of the middleclass interviewees, only Sari had returned to work when her child was under 1 year old, and this was due to the opportunity both she and her spouse had to reduce their working hours. This enabled them to take care of their child at home and they were planning to do it "at least until the child is one and half years old."

It has been argued that family leave schemes give women a (temporary) chance to stay at home to take care of their child(ren), but it depends not on the individual woman, but on the labor market whether, and how soon, the women return to work (Salmi, 2006: p. 163). This was the case among several of the middle-class interviewees; the timing of their return to work was not a question of choice, but depended more on the situation in the local labor market. Returning to work from childcare leave was not a straightforward process, but had demanded a lot of time and effort in seeking employment during childcare leave (Maria), settling for a job that does not match your formal education (Johanna), or employing oneself, either starting as an entrepreneur (Ulla) or as a project worker (Riikka).

\section{Mothers' position in the local labor market}

The interviewees in the working-class mothers' group viewed their situation and the situation of mothers of small children in general in the labor market as quite good. Six of the eight interviewees had had a job to return to after child care leave. Liisa described the overall employment situation in her circle of acquaintances, saying that "I don't see unemployment amongst mothers in my close social circle. I have only one friend with no occupation, who has another child coming, but she still has a permanent job." Workingclass mothers were more flexible in choosing where they work than middle-class mothers; for example, Iiris was working as a service person in a job that did not require formal qualifications and Janina was planning to work irregular shifts as a cashier until she could gain her degree from vocational school.

The middle-class interviewees saw the overall situation of mothers of small children in the labor market as quite bleak. The interviewees, who had invested years in gaining a degree, were searching for work in their own area of expertise and probably would not settle for something that did not match their educational qualifications. The only exception in the middle-class mothers' group was Johanna, a migrant who was working part-time in an occupation that did not match her educational background. Johanna's decisions seem atypical for a middle-class, high-educated woman who described being "a workaholic" before having her child. However, as noted earlier in the analysis, Johanna expressed strong "primarily mother" views on reconciling work and childcare. She was also aware that if she wanted to work part-time and stay in Jyväskylä (and in Finland), she would have to make sacrifices regarding the content of the work. She had considered moving back to her home country, but realized that it would be financially impossible to work part-time as a single mother in her home country. Although her current occupation did not match her occupational background, Johanna expressed that she is "really grateful and the 
work, even though it's completely different from my educational background, but it's still ok (laughs), it is fine.” Johanna's decisions regarding employment were done in the context of her "primarily mother" understandings of caring for her child and in the context of the challenging situation in the local labor market. Employing herself part-time, even if it meant settling for a job that did not match her educational qualifications, enabled her to "buy" more time with her child, which was her main priority.

The interviewees in the middle-class mothers' group felt that being a mother was something that potential employers view as undesirable for their workers. Maria said she had left the fact that she has a child out of her CV. Getting work was hard, because the city is "full of qualified and over-qualified job-seekers." Both Maria and Noora had graduated from female-dominated fields from university and were aware of the challenges in finding employment in Jyväskylä. Ulla, a highly educated mother of four children, saw entrepreneurship as her only chance of employment in the city. Being over 40 and staying at home with her children for long periods of time, she felt she "didn't have the guts to fill applications and beg for somebody to interview me and then try to justify that I've been with the kids at home for many years, but I'm still a good person."

Jokinen (2013: p. 6) has argued that the education of our time makes people "unsecure investors in the self." Education does not necessarily function as a pathway for upward social mobility anymore and highly educated individuals are facing a new kind of insecurity in the labor market. This became apparent in the way the interviewees in the middle-class mothers' group talked about their situation in the labor market-several of them could be described as "unsecure investors in the self," who had put considerable effort into their education and in finding employment at the local labor market without having any guarantees of getting a job. For the middle-class interviewees, the cultural capital acquired through education was not always easily converted to symbolic capital and economic reward in the context of local labor market (cf. Skeggs, 1997: p. 161). This was experienced by middle-class Maria, who had been working during the weekdays in Helsinki before she had a child. After moving to Jyväskylä, Maria had been searching for who had been searching for a job suitable for her skills during the childcare leave. She contrasted the labor market in Helsinki to the labor market in Jyväskylä stating that "in Helsinki, the job markets would be totally different. It would be really easy to get a job and also to get more challenging jobs." In the end, she had managed to get a job from her own field through her social contacts: "In here [Jyväskylä], you have to stand out from the crowd and quite frankly, you have to know someone in order to even get a job interview."

\section{Conclusion}

The aim of this study was to examine the ways in which social class shapes the return-towork decisions of working-class and middle-class mothers, and how these decisions are structured by the constraints and opportunities mothers face in the local labor market. The findings presented that both working-class and middle-class mothers hold similar kind of "gendered moral rationalities" (Duncan, 2005) when it comes to combining paid work and childcare. However, gendered moral rationalities were not static positions for the interviewees: the interviewees emphasized the "primarily mother" understandings that shifted toward the "primarily worker" views once the child was seen as old enough 
to enroll in daycare. The interviewees in both groups emphasized the importance of work as a separate role from mothering and the factors that motivated them to return to work were similar in both groups. The biggest differences regarding the orientations toward work were on the emphasis the middle-class interviewees had on the content of work, whereas the working-class interviewees had a more practical orientation toward work. However, the experiences of interviewees of this study do not fit into the dichotomy of working-class work as a financial necessity and middle-class work as free choice (cf. Hebson 2009; James, 2008). This might be due to the differing societal contexts of the previous studies regarding work orientations between working-class and middleclass mothers. Several of these studies have been conducted in Britain, where differences between social classes are often found to be more striking than in the Nordic countries. Finland also has a long tradition for women's full-time employment and a strong cultural norm of the dual-worker/dual-carer model for mothers regardless of social class (e.g., Julkunen, 2010), which can also explain the relatively minor differences in work orientations between the working-class and the middle-class interviewees.

In both groups, the interviewees expressed strong motivation to work and "primarily worker" understandings regarding the reconciliation of work and childcare once the child was considered to be old enough for daycare enrollment, but the interviewees were faced by different structural constraints when making their return-to-work decisions. The financial situation of the family was crucial for working-class women when deciding about their return to work. Several of the working-class mothers pointed out that they would not have returned to work as quickly if their families' financial situation had been better. For some of the working-class interviewees, the financial need to return back to employment sooner than what they saw as best for their children caused ambivalent feelings, conflicting their "gendered moral rationalities." In the middle-class mothers' group, none of the interviewees indicated that financial situation had been central to their decision-making regarding returning to work, or at least it was not expressed as openly. This might also be due to the social context of focus groups, the expressing of worries about financial situation being "more acceptable" in the working-class mothers' group. For several of the middle-class mothers, getting a job in their own field had been challenging, which affected their timing of returning to work. Only two of the six interviewees had had a job to return to after childcare leave, as compared with six of the eight interviewees in the working-class mothers' group. The middle-class mothers reported both difficulties in finding employment suitable for their skills and insecurity about the permanency of their current jobs.

Contradictory to previous research, the analysis of this article highlights the precarious employment situation of high-educated, middle-class mothers. Previous research on maternal employment and work-family reconciliation in Finland has shown that mothers with higher education usually have more latitude when making decisions regarding employment and childcare leave and the women who face biggest challenges in finding employment after having children are mothers with low educational level (e.g., LammiTaskula, 2004). This is because of the challenging situation the high-educated mothers are now facing in the local labor market of Jyväskylä. During the recession, the relative rate of unemployment for high-educated has soared in the Central Finland region (Ministry of Employment and the Economy, 2015). The national employment rates for mothers, especially for mothers of young children, are higher than the employment rates of mothers in Jyväskylä. As noted in the research report by Kuronen and Kröger (2011), 
one of the reasons for this might be the challenging situation in the local labor market, and especially the difficulties faced by young, recently graduated women at the start of their working careers.

When the discourse of choice (see Varjonen, 2011) gets significant emphasis in the public discussion regarding Finnish childcare policy, it becomes more and more important to understand the factors that shape mothers decisions regarding childcare and returning back to employment. Reducing the discussion to "choice" fails to take in consideration that mothers' decisions about employment and childcare are not done in a social or cultural void, but they are affected by a variety of factors, such as the labor market, opportunities for employment, economic situation of the family, and the cultural idea(1)s about good mothering (i.e., the "gendered moral rationalities"). The analysis of this article highlights particularly the importance of taking the local level factors also into consideration; the "structure of opportunities" (Ellingsæter, 2006: p. 122) childcare policies generate on a national level can be different not only to women of different social classes but also to women in different geographical locations.

However, with a small sample size, caution must be applied and empirical generalizations cannot be drawn from the data. Also as pointed out by Krueger (1988: p. 42), focus group results are "more exploratory and illuminating than suitable for projection to a population." Although the current study is based on a small sample of participants, the findings suggest the importance of studying not just the overall country level of maternal employment but also of focusing on the possibilities and obstacles women face in the local labor market in their day-to-day lives. For further study, more research is needed on the role of local labor markets in maternal employment and in the overall opportunities and constraints that affect mothers' work-family reconciliation.

\section{References}

Anttonen, A. (2003) Lastenhoidon kaksi maailmaa. (Two worlds of childcare) In: Forsberg, H. \& Nätkin, R. (eds.) Perhe murroksessa. Kriittisen perhetutkimuksen jäljillä. (Families in transition. Essays in critical family studies) Helsinki, Gaudeamus, pp. 159-185.

Braun, V. \& Clarke, V. (2006) Using thematic analysis in psychology. Qualitative Research in Psychology, 3(2): 77-101.

Chou, Y. C. \& Kröger, T. (2014) Reconciliation of work and care among lone mothers of adults with intellectual disabilities: The role and limits of care capital. Health \& Social Care in the Community, 22(4): 439-448.

City of Jyväskylä (2011) Hyvinvointikertomus. (Welfare report) [Online] Available from: http://www.jyvaskyla.fi/instancedata/prime_product_julkaisu/jyvaskyla/embeds/jyvaskylawwwstructure/51192_hvk_2011a.pdf [Accessed March 16, 2015].

Damaske, S. (2011) For the family? How class and gender shape women's work. Oxford, Oxford University Press.

Duncan, S. \& Edwards, R. (1999) Lone Mothers, Paid Work and Gendered Moral Rationalities. Basingstoke, Macmillan.

Duncan, S. (2005) Mothering, class and rationality. The Sociological Review, 53(2), 50-76.

Ellingsæter, A. L. (2006). The Norwegian childcare regime and its paradoxes. In: Ellingsæter, A.L \& Leira, A. (eds) Politicising parenthood in Scandinavia. Gender relations in welfare states Bristol, The Policy Press, pp. 121-144.

Erola, J. (ed.) (2010) Luokaton Suomi? Yhteiskuntaluokat 2000-luvun Suomessa. (ClasslessFinland? Social classes in $21^{\text {st }}$ century Finland.) Helsinki, Gaudeamus. 
Esping-Andersen, G. (2015) Welfare regimes and social stratification. Journal of EuropeanSocial Policy 25(1): 124v134.

Forsberg, L. (2009) Involved parenthood: Everyday lives of Swedish middle-class families. Linköping, Linköping University Electronic Press.

Goldthorpe, J. H. (1980) Social mobility o class structure in modern Britain. Oxford, Claren don Press.

Grødem, A. S. (2015) A review of family demographics and family policies in the NordicCountries. Baltic Journal of Political Science 3(3), 50-66.

Hebson, G. (2009) Renewing class analysis in studies of the workplace: A comparison ofworking-class and middle-class women's aspirations and identities. Sociology 43(1), 27-44.

Heikkilä, R. (2008) Puhuva ryhmä: esimerkkitapaus ryhmähaastattelun käytöstä sosiaalitieteellisessä tutkimusasetelmassa. (The speaking group: An example on the use of group interview in the social scientific research design.) Sosiologia 45(4), 292-305.

Hernes, H. (1987) Welfare state and woman power: Essays in state feminism. Oslo, Norwegian University Press.

Hiilamo, H. \& Kangas, O. (2006) Trap for women or freedom to choose? Political frames in the making of child home care allowance in Finland and Sweden. Turku, Department of Social Policy, University of Turku.

Hochschild, A. R., with Machung, A. (1989) The Second Shift. New York, Avon.

James, L. (2008) United by gender or divided by class? Women's work orientations and labourmarket behaviour. Gender, Work \& Organization 15(4), 394-412.

Jokinen, E. (2005) Aikuisten arki. (Everyday life of adults.) Helsinki, Gaudeamus.

Jokinen, E. (2013) Prekaari sukupuoli. (Precarious gender.) Naistutkimus, 26(1), 5-16.

Julkunen, R. (2010) Sukupuolen järjestykset ja tasa-arvon paradoksit (The orders of gender andthe paradoxes of equality). Tampere, Vastapaino.

Kauhanen, M. (2013) Sukupuolten väliset erot työpaikkojen laadussa - onko työsuhteen tyypilläväliä? (Gender differences on quality of jobs. Does the type of employment matter?) In: Pietiläinen, M. (ed.), Työ, talous ja tasa-arvo (Employment, Economies and Equality). Helsinki, Statistics Finland, pp. 49-64.

Kauppinen, K. \& Raitanen, J. (2011) Perhevapaalta takaisin työelämään - Erilaiset ratkaisuterilaisissa perhe- ja elämäntilanteissa. (From family leave back to work - Different solutions in differing family and life situations.) In: Luoto, R., Kauppinen, K. \& Luotonen A. (eds.), Perhevapaalta takaisin työelämään. (Back to working life from family leave.) Helsinki, Finnish Institute of Occupational Health, pp. 13-53.

Kela (2010) Isien osuus perhevapaista kasvaa hitaasti mutta varmasti. (Father's use of parental leave is growing slowly but steadily.. [Online] Available from: http://uudistuva.kela. fi/it/kelasto/kelasto.nsf/alias/TK_2010_11_12/\$File/TK_2010_11_12_Isien_osuus_perhevapaista_kasvaa.pdf [Accessed 24 ${ }^{\text {th }}$ June 2014].

Kela (2014) Benefits for families with children. [Online] Available from: http://www.kela.fi/ web/en/families;jsessionid=C71904C0D4B987EABFF37B8B4772241D [Accessed June 24, 2014].

Kelhä, M. (2008) Äitiys, luokka, ikä. (Motherhood, class, age.) In: Tolonen, T. (ed.), Yhteiskuntaluokka ja sukupuoli. (Social class and gender.) Tampere, Vastapaino, pp. 82-100.

Krueger, R. A. (1988) Focus groups: A practical guide for applied research. London, Sage.

Kuronen, M. \& Kröger, T. (2011) WP 1: Degree and structures of women's labour market

Integration. Local report, City of Jyväskylä, Finland. (Unpublished research report)

Käyhkö, M. (2006) Siivoojaksi oppimassa: Etnografinen tutkimus työläistytöistä pubdistuspalvelualan koulutuksessa. (Learning to Become a Cleaner. Ethnographic Study of Working-class Girls in Cleaning Services Education.) Joensuu, Joensuu University Press.

Lammi-Taskula, J. (2004) Äidit työmarkkinoilla - kahden kerroksen väkeä? (Mothers on labor market - two level population?) Yhteiskuntapolitiikka, 69(2), 202-206. 
Lewis, S. (1991) Motherhood and employment: The impact of social and organizational values. "In: Phoenix, A., Woollett, A. \& Lloyd, E. (eds.) Motherhood: meanings, practices and ideologies. London, Sage, pp. 195-215.

Luotonen, A. (2012) Äitien paluu perhevapaalta työhön - Motivaatio ja strategiat. (Mothers' return from family leave to work - Motivation and strategies.) Research report 42. Helsinki, Finnish Institute of Occupational Health, pp. 78-126.

Luotonen, A. (2013) Mothers' return to work: Contradictions, negotiations and strategies. In: Oinonen, E. \& Repo, K. (eds.), Women, men and children in families: Private troubles and public issues. Tampere, Tampere University Press, pp. 29-54.

Mikkelä, E. (2013) Naisten ja miesten ammatit ja työt. (Female and male occupations and work.) In: Pietiläinen, M. (ed.), Työ, talous ja tasa-arvo. (Employment, Economies and Equality.) Helsinki, Statistics Finland, pp. 65-82.

Ministry of Employment and the Economy (2015) Työttömät työnhakijat koulutusasteen mukaan Keski-Suomi (Unemployed job-seekers according to educational level, Central Finland) Available from: http://www2.toimialaonline.fi/graph/Graphpage.aspx?ma=028Ty*246;tt*246;m*228;t_ty*246;nhakijat_ALL_SEL\&path=../QUICKTABLES/ KESKI-SUOMI/040_TY*214;MARKKINAT/\&ssid=1503171657217\&Gedit=False\&case $=$ qt $\& A C T I O N$ [Accessed March 17, 2015].

Morgan, D. L. (1997) The Focus Group Guide Book. London, Sage.

National Institute of Health and Welfare (2014) Lasten päivähoito 2013. (Day care of children 2013.) Helsinki, National Institute of Health and Welfare.

Pietilä, I. (2010) Ryhmä- ja yksilöhaastattelun diskursiivinen analyysi: Kaksi aineistoa erilaisina vuorovaikutuksen kenttinä. (The discursive analysis of group and individual interviews: Two data sets as different fields of interaction.) In Ruusuvuori, J., Nikander, P. \& Hyvärinen, M. (eds.) Haastattelun analyysi. (Interview Analysis) Tampere, Vastapaino, pp. 212-241.

Salmi, M. (2006) Parental choice and the passion for equality in Finland. In: Ellingsaeter, A.L. \& Arnlaug, L. (eds.), Politicising parenthood in Scandinavia. Gender relations in welfare states. Bristol, Policy Press, pp. 145-170.

Skeggs, B. (1997) Formations of class \& gender. London, Sage Publications.

SOTKANet (2015a) Unemployed people, as \% of labour force [Online] Available from: http:// uusi.sotkanet.fi/taulukko/Wx3/92,93,94,95,96,97,98,99,100,101,102,103, 104,105,106, 107,108,109,110,111,112,113,114/7/3A/0/181/ [Accessed March 13, 2015].

SOTKANet (2015b) Children aged 1-6 in municipally funded day care, as \% of total population of same age.[Online] Available from: https://www.sotkanet.fi/sotkanet/en/tauluk$\mathrm{ko} /$ ? indicator $=\mathrm{s} 64 \mathrm{qt} 070 \mathrm{sNY}$ tMrQ21jMEAA $==$ \&region $=$ szbMsbaIAgA $=\& y e a r=s y 4 \mathrm{r}-$ tTbX0zUEAA==\&gender=t [Accessed May 31, 2015].

Statistics Finland (2013) Large share of mothers at home caring for children without employment contract. [Online] Available from: http://www.tilastokeskus.fi/til/tyti/2013/14/ tyti_2013 14_2014-10-07 kat 004 en.html [Accessed June 3, 2015].

Statistics Finland (2014)Averagemonthlyearnings by employersector andgender.[Online] Available from: http://www.stat.fi/til/ati/2014/01/ati 201401 2014-05-28 tau 011 en.html [Accessed July 21, 2014].

Statistics Finland (2015) Employment weakened slightly in 2014, men's and women's employment rates came closer to each other. [Online] Available from: http://www.stat.fi/til/ tyti/2014/13/tyti 201413 2015-04-28 tie 001 en.html [Accessed June 3, 2015].

Stefansen, K., \& Farstad, G. R. (2010). Classed parental practices in a modern welfare state: Caring for the under threes in Norway. Critical Social Policy, 30(1), 120-141.

Sutela, H. (2013) Määräaikainen työ ja perheellistyminen. (Fixed-term work and starting a Family.) In: Pietiläinen, M. (ed.), Työ, talous ja tasa-arvo. (Employment, Economies and Equality.) Helsinki, Statistics Finland, pp. 93-110. 
Tervo, H. \& Korhonen, R. (1994) Paikalliset työmarkkinat ja niiden tyypit Suomessa. (Local labour markets and their clusters in Finland.) Work research unit, University of Jyväskylä, Research reports 12 .

Tolonen, T. (ed.) (2008) Yhteiskuntaluokka ja sukupuoli. (Social class and gender.) Tampere, Vastapaino.

Varjonen, S. (2011) Äidin hoiva, jaettu vanhemmuus - ja vapaus valita. Perhevapaiden undistamisen argumentointi 1970-luvulta 2000-luvulle. (Mother's care, shared parenthood - and freedom to choose. Argumentation in Finnish parental leave reforms from 1970s to 2000s.) Studies in social security and health 118 . Helsinki, Kela.

Walkerdine, V. \& Lucey, H. (1989) Democracy in the kitchen. Regulating mothers and socializing daughters. London, Virago Press.

Walkerdine, V., Lucey, H. \& Melody, J. (2001) Growing up girl-Psychosocial explorations of gender and class. London, Palgrave.

Wheatley, D. (2013) Location, vocation, location? Spatial entrapment among women in dual career households. Gender, Work \& Organization 20(6): 720-736.

Yeandle, S. (2009) Introduction. In: Yeandle, S. (ed.) Policy for a Change: Local Labour Market Analysis and Gender Equality. Bristol, Policy Press, pp. 1-9. 